\title{
お辞儀の主観的印象と社会的文脈に対する適切さ
}

\author{
柴田 寛 東北文化学園大学 高橋 純一 福島大学 行場 次朗 東北大学
}

\section{Subjective impressions of bowing actions and their appropriateness in specific social contexts}

\author{
Hiroshi Shibata (Tohoku Bunka Gakuen University), Junichi Takahashi (Fukushima University), \\ and Jiro Gyoba (Tohoku University)
}

\begin{abstract}
The current study used video clips of bowing actions depicted by three-dimensional computer graphics. The bend angle $\left(15^{\circ}\right.$ and $\left.45^{\circ}\right)$ and duration of the bent posture (0-4.5 seconds) were varied. In the first experiment, the participants rated their subjective impressions of the bowing actions. The bowing actions that were made at a $45^{\circ}$ angle and held for more than 1 second were rated as courteous. Bowing motions held for shorter durations were rated as smooth. In the second experiment, the participants evaluated whether a bowing action was appropriate for a specific social context. The participants judged $15^{\circ}$-angle bowing of no / very short duration appropriate for greeting, $45^{\circ}$-angle bowing of no / short duration appropriate for gratitude, and $45^{\circ}$-angle bowing for about 2 seconds appropriate for an apology. The results of these two experiments are discussed in terms of how angle and duration influence the impressions and evaluations of the appropriateness of a bowing action.
\end{abstract}

Key words: bowing action, bend angle, bent posture duration, subjective impression, appropriateness evaluation.

The Japanese Journal of Psychology

2015, Vol. 85, No. 6, pp. 571-578

J-STAGE Advanced published date: November 11, 2014, doi.org/10.4992/jjpsy.85.14005

人間は社会的な生き物であり，他者との円滑なコ ミュニケーションは社会生活を営む上で非常に重要で ある。他者とのコミュニケーションには言語的なもの に加えて姿勢や動作などを含む非言語的なチャンネル がある（大坊，1998）。日本人に頻繁に用いられる非 言語コミュニケーションのひとつとして，括辞儀が挙 げられる。お辞儀は挨拶に限定されず，謝罪や感謝の 気持ちをあらわす場面などでも用いられており，日常 の中で広く見られる動作である。括辞儀が他者に与え る印象を明らかにすることは, 円滑な人間関係を形成 したり維持したりする上での重要な知見になると思わ れる。

お辞儀には立礼と座礼があり，どちらも上体を屈す る角度による分類がある（古閉, 2012; 松村, 1967; 小 笠原, 1975; 小笠原, 2007; 柴崎, 2008)。分類は古閑 (2012）にまとめられているが，たとえば立礼では会

Correspondence concerning this article should be sent to: Hiroshi Shibata, Department of Rehabilitation, Faculty of Medical Science and Welfare, Tohoku Bunka Gakuen University, Kunimi, Aoba-ku, Sendai 981-8551, Japan (e-mail: hshibata@rehab.tbgu.ac.jp)

本研究は日本認知心理学会第 11 回大会で発表された。
釈 (15 度), 敬礼 (30 度), 最敬礼 (45 度), 拝礼 (90 度）の 4 つの分類（古閑, 2012）や，もっとも簡単な 会釈 (15 度くらい), 普段用いられる敬礼 $(45$ 度くら い), 神仏に用いる最敬礼 (90 度くらい) の分類 (柴崎, 2008）などがある。このほか, 小笠原（2007）は浅い 礼, 普通の礼, 深い礼に分けており, 屈体に伴って移 動する手の位置にもとづいてこれらの礼を説明してい る。

お辞儀の動作のタイミングとしては，吸う息で体を 屈して，吐く息だけ静止させ，吸う息で体を起こす三 息が標準であるとされ, 礼三息と呼ばれている（松村, 1967; 小笠原, 1975; 小笠原, 2007; 柴崎, 2000, 2008)。 三息を標準とすることで呼気と共に状態を動かすこと になり，美しい姿勢を保てるという（柴崎, 2000）。

実験的に㧍辞儀を検討した研究は多くはないもの の, 田中（1989）は大学生が 45 度屈体する立礼動作 を対象とした動作の分析を行っている。はじめに学生 本人が丁寧だと思う動作を分析したところ, 学生間の 平均では体を屈する時間が 1.6 秒, 屈体後に静止する 時間が 1.0 秒, 体を伸展する時間が 1.5 秒となり, 手 本となる人物の動作と比べると特に静止時間に大きな 差があること, また指導後の動作分析では, 指導前に 
比べて静止時間と伸展時間が長くなり, 学生間のばら つきが減少したことを報告している（手本動作は屈体 時間が 1.3 秒, 静止時間が 1.9 秒, 伸展動作が 1.6 秒 であった。ただしわかりやすくするため教師は静止と 伸展の時間を意識的に長く演じていた)。さらに普段 の挨拶で用いられる軽いお辞儀（たとえば友人間で行 われるお辞儀) を分析した結果も報告しており，この ような場面では短く頭を下げるだけであり，屈体から 伸展までのトータルでの平均時間は 1.2 秒であること を記載している。このほか森下・岩下（1985）は, 一 般学生では熟練者に比べて屈体後の静止時間が短くな ることを報告している。辺見・諌山（2010）は 3 次元 コンピュータグラフィックス $(\mathrm{CG})$ で作成した 45 度 屈体する立礼動作刺激を用いて, 立礼動作の好まれる 挙動時間を調べている。その結果, 屈体, 静止, 伸展 の三つの動作すべてにおいて 1.5 秒程度の時間が好ま れることを示している（ただし屈体はやや短く，伸展 はやや長い時間が好まれる傾向も報告している)。

以上のように熟練者と非熟練者とのお辞儀動作の差 異や好まれる挙動時間について報告されてきている が, それでは, 運動の特徵が異なるお辞儀はその受け 手にどのような印象を与えるのであろうか。また，特 徵の異なるお辞儀は様々な文脈においてどのように使 いわければよいのであろうか。先行研究として, 福岡・ 柴田・行場（2008）は実験者自身が㧍辞儀動作を行う 映像刺激を用いてその印象を調べることを試みている が, 人間が行う動作では実験刺激の運動情報の正確な 操作が難しいことが問題となる。また，先述したよう に辺見・諌山（2010）は CG で作成した刺激を用いて いるが, 好まれる挙動時間を調べるにとどまっている。

本研究では, 運動情報のみを操作した, $\mathrm{CG}$ で作成 したお辞儀動作刺激を用いて，その動作に対する主観 的印象と社会的文脈に打ける適切さを調べる二つの実 験を行った。運動情報としては屈体角度と屈体後の静 止時間を操作した。屈体角度の区分は文献により違い があるが, 複数の先行研究で分析対象とされている 45 度を取り上げ，さらに柴崎（2008）を参考に, 普 段用いられる立礼動作として, 敬礼（45 度）のほか に会釈（15 度）を加えた 2 種類を用いた。また, 静 止時間は 0 秒から 4.5 秒まで 0.5 秒ずつ変化させた 10 種類として，非熟練者によく見られる静止時間が短い 動作だけでなく，静止時間が長い動作の印象について も検討した。

実験 1 ではセマンティック・ディファレンシャル （SD）法を用いて立礼動作に対する主観的印象を調べ た。SD 法で用いる形容詞対については㧍辞儀動作の 印象を調べた福岡他（2008）の研究（お辞儀動作の観 察による自由記述で得られた形容詞などを使用）と， 柴崎（2004）が礼儀に関する調査で用いたものにもと づき選択した。
実験 2 では立礼動作が行われる社会的文脈を操作し て，どの文脈でどのような立礼動作が適切だと判断さ れるのかを調べる実験を行った。小熊・馬場・広田・ 越前谷（2004）は教師と学生との間で行われる会話と 非言語行動を分析しており，お辞儀は感謝や詫びなど に関連する言葉にともなって現れることを報告してい る。古閑 (2012) も, 挨拶のほか, 感謝や謝罪の意を あらわすときに括儀が用いられると述べている。本 研究では挨拶, 感謝, 謝罪の場面を取り上げて, これ らの文脈においてどのような立礼動作が適切と判断さ れるのかを調べることを目的とした。

\section{実 験 1}

\section{目 的}

お辞儀の屈体角度と屈体後の静止時間を操作して, その受け手が抱く主観的印象を調べることを目的とし た。

\section{方 法}

参加者 大学生および大学院生 24 名であった。回 答に不備のあった 1 名を除く 23 名 $(20-25$ 歳：男 性 11 人，女性 12 人）を分析対象とした。

刺激 身体モデリングソフトウェアの Poser 8 (Smith Micro Software 社) を用いてCGのマネキンが立礼動 作を行う映像（1秒間 30 フレーム）を作成した（Figure 1)。動作は観察者と対面する方向のみを用いた。腰を 軸として頭を下げ，小笠原（1975）や柴崎（2008）を 参考に頭が下がるにつれ手は腿に沿って前に出るよう にした。頭を下げる屈体角度（15 度，45 度）と頭を 下げた後の静止時間 ( 0 秒, 0.5 秒, 1 秒, 1.5 秒, 2 秒, 2.5 秒, 3 秒, 3.5 秒, 4 秒, 4.5 秒) を操作して計 20 種類の動作を作成した。屈体にかかる時間は 15 度で は 0.67 秒, 45 度では 1.5 秒とした(伸展も同一の時間)。 小笠原（1975）によれば屈体の速度は角度によらず一 定にすべきとあり, 本研究では角度によらず屈体, 伸 展する速度は一定とした。1 フレームあたりの最大の 角度変化は屈体角度によらず一定とした。屈体角度に よらず動作の開始と静止に近いフレームでは動作変化 を緩やかにした（運動開始直後の8 フレームで変化す る角度を徐々に増加させていき, 静止直前の 8 フレー ムで徐々に減少させた)。映像は 1 秒間の正立姿勢か ら始まり，その後に屈体動作が開始された。伸展動作 の終了後にも 1 秒間の正立姿勢を入れた。

形容詞対 福岡他 (2008) と柴崎 (2004) の研究で 用いられた形容詞対にもとづいて 20 項目を選定した (Table 1)。

手続き 評定に対する基準を与えることを目的とし て，参加者にはまず CRT デイスプレイに 20 種類の立 礼動作刺激をランダムな順序で提示して，それらを観 
察してもらった。参加者は $60 \mathrm{~cm}$ の距離から映像を観 察した。立礼動作刺激の視角（背景含む）は縦 12.8 度 $\times$ 横 10.3 度であった。次に参加者は各映像刺激に 対して SD 法による評定を行った。同一の立礼動作が 2 回繰り返される映像を観察した後, 20 項目の形容詞 対について7段階尺度で評定した。参加者は自分の ペースで次の映像をスタートさせて，20 種類の立礼 動作について評定した。参加者間で形容詞対の極性と その順番を入れ替え, 各立礼動作映像の提示順序もラ ンダムにした。

\section{結果と考察}

各参加者の各立礼動作映像に対する評定值をもとに 因子分析 (主因子法) を行った。固有值の変化は 8.19, $5.05 ， 1.23 ， 0.77 ， 0.74$ と続き，第 3 因子から小さい 值をとったため因子数は 2 に設定した。共通性が低い 形容詞対（“地味な一派手な”, 共通性 0.11）を取り除き, 19 項目について再度因子分析を実施した。抽出後の 負荷量平方和は 2 因子の累積で $65.7 \%$ であった。回 転後（プロマックス回転を用いた）の因子パターンを Table 1 に示す。斜交回転を用いたが因子間相関係数 は 0.13 であり 0 に近い值であった。

第 1 因子は“丁寧な-ぞんざいな”，“礼儀正しい-無 礼な”，“真面目な一不真面目な”などの形容詞対が高 い因子負荷量を示した。これら因子負荷量の高い形容 詞対は類似した概念と考え, 最も因子負荷量の高い形 容詞対から“丁寧さ”と命名した。第 2 因子は“スムー ズなースムーズでない”、“親しみやすい-親しみにく い”, “違和感のない-違和感のある”などの形容詞対 が高い因子負荷量を示した。これらの形容詞対は動き の滑らかさや，それと反対の意味を持つ動きのぎこち なさや不自然さに関連すると考え“滑らかさ”と命名 した。
Table 1

プロマックス回転後の因子負荷量

\begin{tabular}{lcc}
\hline 形容詞対 & 第 1 因子 & 第 2 因子 \\
\hline 丁寧な-ぞんざいな & 0.92 & -0.17 \\
礼儀正しい-無礼な & 0.92 & -0.07 \\
真面目な-不真面目な & 0.91 & -0.18 \\
上品な-下品な & 0.83 & 0.01 \\
関心のある-関心のない & 0.79 & -0.02 \\
美しい-みにくい & 0.79 & 0.28 \\
満足な-不満足な & 0.79 & 0.20 \\
能動的な-受動的な & 0.74 & 0.01 \\
積極的な-消極的な & 0.73 & 0.05 \\
澄んだ-濁った & 0.56 & 0.37 \\
\hline スムーズな-スムーズでない & 0.01 & 0.82 \\
親しみやすい-親しみにくい & 0.22 & 0.78 \\
違和感のない-違和感のある & 0.30 & 0.77 \\
自然な-不自然な & 0.25 & 0.77 \\
気楽な-堅苦しい & -0.57 & 0.74 \\
やわらかい-かたい & -0.26 & 0.73 \\
普通な-特別な & -0.43 & 0.69 \\
開放的な-閉鎖的な & 0.03 & 0.63 \\
健康的な-不健康な & 0.39 & 0.54 \\
\hline
\end{tabular}

条件ごとの参加者間の各因子得点の平均值を Figure 2 に示す。因子得点について因子ごとに 2 要因分散分 析（屈体角度（2）×静止時間（10））を行った。丁寧 さについては, 屈体角度の主効果 $(F(1,22)=126.14$, $p<.001)$ と静止時間の主効果 $(F(9,198)=10.56, p$ <.001）が有意であり交互作用 $(F(9,198)=1.59, n s)$ は有意でなかった。屈体角度の結果は, 15 度よりも 45 度の方が丁寧さの得点が高いことを示す。静止時

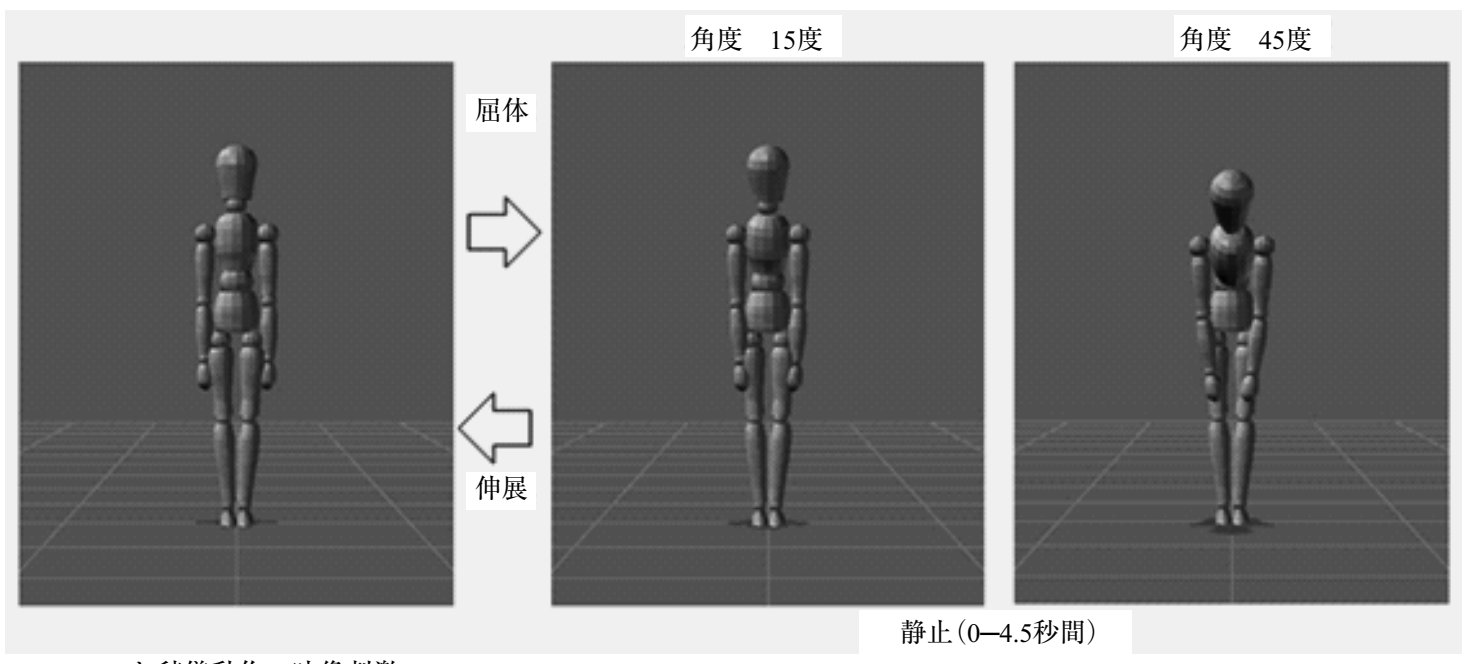

Figure 1. お辞儀動作の映像刺激 
間については, Figure 2 からは 15 度, 45 度ともに静 止時間が 0 秒から増加するにしたがって得点が上昇し ていき, 1 秒程度でピークに達し, それ以降緩やかに 下降する変化が見て取れる（得点が最も高い条件は 15 度では 1 秒条件, 45 度では 1.5 秒条件, 角度条件 を平均すると 1 秒条件であった)。静止時間の主効果 についてピークの静止時間 1 秒条件に着目して多重比 較 (以下, 多重比較はRyan法を用いた。有意水準は 5\%) を行ったところ， 1 秒条件では 0 秒条件と 0.5 秒条件 よりも得点が有意に高く, 1.5 秒以降の各条件とは有 意な差は認められなかった。これらの結果は, 静止時 間が短いと丁寧さの得点は低いこと, 静止時間が 1 秒 程度で最も丁寧さの得点が高くなること, 静止時間が 長くなっても得点は比較的高く保たれている（ピーク との有意差は認められない)ことを示している。

滑らかさについては, 静止時間の主効果 $(F(9)$ 198） $=30.30, p<.001 ）$ が有意であり，屈体角度の主 効果 $(F(1,22)=1.02, n s)$ と交互作用 $(F(9,198)=0.56$, $n s)$ は有意でなかった。滑らかさは今回設定した屈体 角度の違いに影響を受けないと考えられる。静止時間 については, Figure 2 からは 0 秒から 1 秒までは得点 が高く保たれており，それ以降は静止時間が長くなる にしたがって得点が低くなっていくことが見て取れる (得点が最も高い条件は 15 度では 1 秒条件, 45 度で は 0.5 秒条件, 角度条件を平均すると 1 秒条件であっ た)。静止時間の主効果についてピークの静止時間 1 秒条件に着目して多重比較を行ったところ，1秒条件 は 0 秒条件, 0.5 秒条件, 1.5 秒条件とは有意な差がな
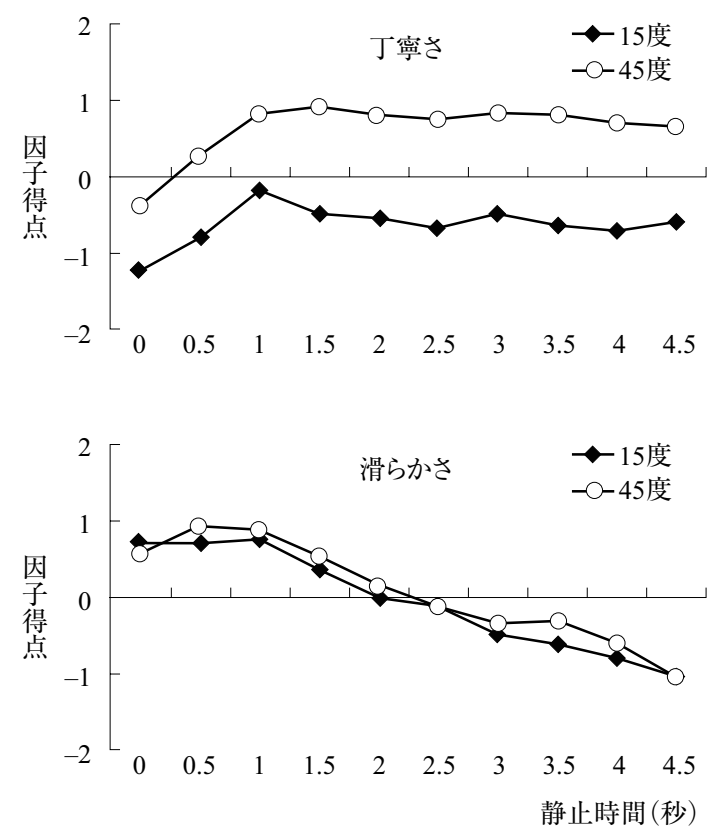

Figure 2. 因子ごとの因子得点
く，2秒以降の各条件とは有意差が認められた。この 結果は, 静止時間が短いと滑らかさの得点は高いこと, 静止時間がある程度長くなると滑らかさの得点は減少 することを示している。

まとめると, 実験 1 ではお辞儀動作に対する主観的 印象を調べたが, その印象に対する因子として丁寧さ, 滑らかさの 2 因子が抽出された。また屈体角度や屈体 後の静止時間の操作に伴う主観的印象の変化のパター ンを明らかにすることができた。

\section{実 験 2}

\section{目 的}

お辞儀を用いる文脈に応じた適切な動作を検討する ことを目的とした。

\section{方 法}

参加者と刺激 実験 1 の終了後に，引き続いて実験 2 が行われた。実験 2 の参加者及びお辞儀動作の刺激 は実験 1 と同じであった。

手続き お辞儀が行われる社会的文脈として“挨拶” “謝罪” “感謝”の場面を設定して，それぞれの場面に おける動作の適切さを評定する実験を行った。参加者 は観察する立礼動作が挨拶のお辞儀としてどれくらい 適切か, また, 謝罪, 感謝の気持ちを伝えるお辞儀と してどれくらい適切かを 7 段階尺度 $(1:$ 非常に不適 切一7：非常に適切）で評定した。参加者には同級生 が参加者自身に対してお辞儀を行っている場面だと想 定して適切さを評定するように教示した2。拈辞儀を 行う相手との関係によってもお辞儀を使い分けるべき だとあり（古閑, 2012; 松村, 1967; 小笠原, 2007), 本 実験では二者間の関係性を同じ立場にそろえた。参加 者は同一の立礼動作映像が 2 回繰り返されるのを観察 した後にその適切さを評定した。参加者は文脈ごとに ランダムな順序で提示される 20 種類の映像刺激の適 切さを評定した。各文脈の順番は参加者間でカウン ターバランスを取った。

\section{結果と考察}

条件ごとの適切さ得点の平均值を Figure 3 に示す。 適切さ得点について文脈ごとに 2 要因分散分析（屈体

\footnotetext{
2 実験者による実験前の教示のほか, 各文脈条件の開始前に 画面上に教示を提示した。たとえば“同級生が自分に対して感 謝の気持ちをあらわすときのお辞儀としてどれくらい適切かを 評定してください”という文章を記載したスライドを提示した。 また，お辞儀映像が終了するごとにたとえば “感謝のお辞儀と しての適切さを評定してください”という文章を提示して，そ の間に参加者は評定用紙に適切さを評定した。評定用紙にも同 様の文脈の教示を記載した。本実験ではこれ以上の具体的な場 面は設定しなかった。
} 
角度 (2) × 静止時間 (10)) を行った。挨拶場面は, 屈体角度の主効果 $(F(1,22)=64.22, p<.001)$, 静止 時間の主効果 $(F(9,198)=71.29, p<.001)$, 交互作 用 $(F(9,198)=2.58, p<.01)$ が有意であった。屈体 角度に着目した単純主効果については, すべての静止 時間で有意差が認められた $(p<.05)$ 。このことはす べての静止時間において 15 度の方が 45 度よりも挨拶 場面での適切さが高いことを示している。静止時間に 着目した単純主効果では二つの角度条件で有意であっ た $(p<.05)$ 。15 度条件, 45 度条件ともに静止時間 が 0 秒のときに適切さ得点が高かったため多重比較は 0 秒条件との比較を実施した。1 15 度条件に着目した多 重比較の結果, 0 秒条件と 0.5 秒条件との有意差は認 められなかったが，0秒条件と 1 秒以降の各条件とは 有意差が認められた。45 度条件に着目した多重比較 の結果， 0 秒条件と 0.5 秒以降のすべての条件と有意 差が認められた。これらの結果は, 屈体後に静止しな い場合に挨拶としての適切さが高いこと, 静止時間が 長くなると適切さが低くなることを示している。

感謝場面は, 静止時間の主効果 $(F(9,198)=28.51$,
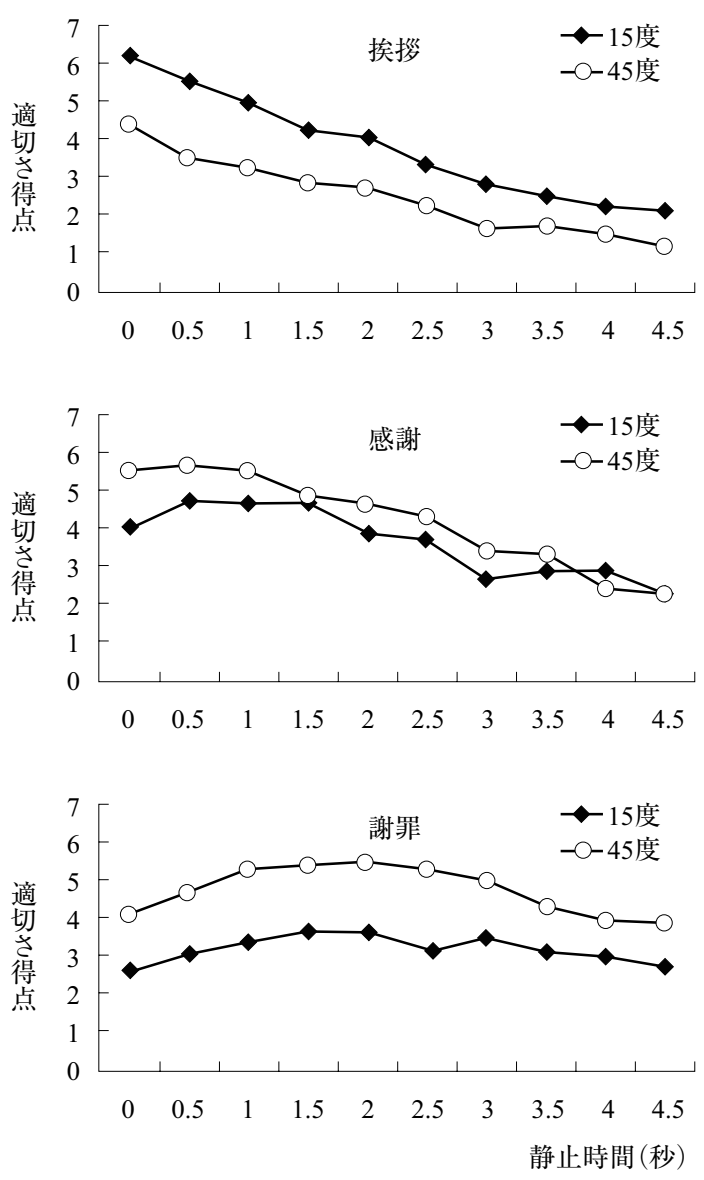

Figure 3. 文脈ごとの適切さ得点 $p<.001)$ と交互作用 $(F(9,198)=2.67, p<.01)$ が 有意であったが，屈体角度の主効果 $(F(1,22)=3.61$, $n s ）$ は有意でなかった。屈体角度に着目した単純主効 果は, 静止時間が 0 秒条件, 0.5 秒条件でのみ有意差 が認められた $(p<.05)$ 。これは静止時間が短い条件 でのみ 15 度よりも 45 度の方が感謝場面の適切さが高 くなることを示している。静止時間に着目した単純主 効果では二つの角度条件で有意差が認められた $(p$ $<.05)$ 。 15 度条件, 45 度条件ともに静止時間が 0.5 秒のときに適切さ得点が最も高かったため多重比較は 0.5 秒条件との比較を実施した。15 度条件に着目した 多重比較の結果, 0.5 秒条件と 0 秒条件とは有意差が 認められなかった。また 0.5 秒条件と 1 秒一 2.5 秒の 各条件とは差が有意でなく, 3 秒以降の各条件とは有 意差が認められた。45 度条件に着目した多重比較の 結果, 0.5 秒条件と 0 秒条件は有意差が認められなかっ た。また 0.5 秒条件と 1 秒一 2 秒の各条件とは差が有 意でなく, 2.5 秒以降の各条件とは有意差が認められ た。これらの結果は, 感謝場面では 0.5 秒程度の静止 時間が適切と評定され, 静止時間が長くなると適切さ が低くなることを示している。

謝罪場面については, 屈体角度の主効果 $(F(1,22)$ $=24.15, p<.001)$ と静止時間の主効果 $(F(9,198)=$ $3.77, p<.001)$ が有意であり, 交互作用 $(F(9,198)$ $=1.00, n s)$ は有意でなかった。屈体角度は 15 度より も 45 度の方が謝罪場面としての適切さが高いことを 示している。静止時間については, 15 度条件, 45 度 条件ともに静止時間が 2 秒のときに最も適切さが高 かったため(ただし 15 度条件の 1.5 秒と 2 秒は同じ值), この条件との多重比較を実施した。その結果，2秒条 件と有意な差が認められたのは 0 秒条件と 4.5 秒条件 のみであった。これらの結果は, 謝罪場面での適切さ は静止時間が 2 秒程度で最も高くなり，屈体後に静止 しない動作や静止時間が非常に長い動作ではその適切 さが低くなることを示している。

次に各場面での立礼動作の適切さが主観的印象とど のように関係しているかを検討するため，実験 1 で得 られた各因子得点と実験 2 で得られた各場面での適切 さ得点との相関関係を調べた。挨拶場面では, 適切さ 得点と丁寧さ得点との相関係数は有意（以下，有意水 準は $5 \%)$ で弱い負の相関関係 $(r=-.317)$ にあり, 適切さ得点と滑らかさ得点との相関係数は有意で弱い 正の相関関係 $(r=.472)$ にあった。感謝場面では, 適切さ得点と丁寧さ得点との相関係数は 0 に近い值 $(r$ $=.091)$ で有意ではなく, 適切さ得点と滑らかさ得点 との相関係数は有意で弱い正の相関関係 $(r=.470)$ にあった。謝罪場面では, 適切さ得点と丁寧さ得点と の相関係数は有意で弱い正の相関関係 $(r=.378)$ に あり, 適切さ得点と滑らかさ得点との相関係数は有意 ではあったが相関係数は非常に小さい值であった $(r$ 
$=.132) 。 こ れ ら の$ 結果は, 弱い相関関係ではあったが, 同級生が行う挨拶場面のお辞儀としては丁寧さが低く 滑らかさが高い印象を与えるほど適切さだと評定され る傾向にあること, 感謝場面のお辞儀としては滑らか さが高い印象を与えるほど適切だと評定される傾向に あること，謝罪場面のお辞儀としては丁寧さが高い印 象を与えるほど適切だと評定される傾向にあることを 示している。

\section{総合考察}

本研究では, 屈体角度と屈体後の静止時間を操作し た立礼動作刺激を用いて，その主観的印象と文脈に応 じた適切さを検討する実験を行った。

実験 1 の結果, 丁寧さと滑らかさの因子が抽出され た。操作した運動情報と各因子得点との関係を調べた ところ，頭を下げる角度が浅い立礼動作（15 度）よ りも深い立礼動作（45 度）の方が動作の受け手に丁 寧な印象を与えることが示された。本研究では 15 度 と 45 度の二つの屈体角度のみ調べたが, 深く屈体す るお辞儀が丁寧な印象と関連している可能性が示唆さ れる。屈体後の静止時間は, 静止させずに体を起こす と丁寧さの印象は低くなるが，静止時間が 1 秒一 1.5 秒程度で丁寧さが最も高くなり，それ以上長くなった 場合も丁寧な印象は比較的高く保たれることがわかっ た。一方, 滑らかさの印象については屈体角度の違い による差は見られず, 静止時間が 0 秒一 1 秒程度で滑 らかな印象を与え，それ以降は静止時間が長くなるに つれて次第に滑らかさが低くなり，ぎこちない印象を 与えることを示す結果となった。

屈体角度が 45 度のお辞儀を用いた先行研究（辺見・ 諌山，2010）からは 1.5 秒程度の静止時間が好まれる こと, お辞儀の動きを観察した先行研究（田中, 1989）でも，熟練者のお辞儀の静止時間が 1.5 秒程度 であることを報告している。本実験は同様の 1.5 秒程 度の静止時間で丁寧な印象を与えることができること を示している。本研究ではさらに，静止時間を長くし ても丁寧さの印象は比較的高く保たれること, ただし 滑らかさには欠けてぎこちない印象を与えることが示 された。礼三息や熟練者のお辞儀を分析した知見（田 中，1989）にもとづくと，本研究で設定した 4.5 秒の 静止時間はかなり長い時間と考えられるが, 丁寧さの

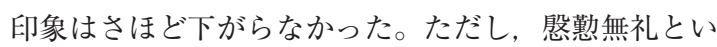
う言葉があるとおり, 過度な丁寧さはかえって無礼な 印象を与える可能性も考えられる。4.5 秒よりもさら に静止時間を長くしたお辞儀動作に対する丁寧さの評 定も検討の必要があるかもしれない。

実験 2 では，同級生が自分に対して行うお辞儀とし ての適切さを評定する実験を行った。挨拶場面では浅 いお辞儀であったり, 静止時間が短いお辞儀であると, 適切さが高く評定された。また, 滑らかさ得点と適切
さ得点は正の相関関係にあり，挨拶場面では滑らかな 印象を与える動作が適切さと関係する結果となった。 挨拶のお辞儀は，感謝や謝罪場面でのお辞儀に比べて 特定の意図や気持ちを伝える必要がなく，日常生活で 用いられる頻度も高いと想定される。そのため, 滑ら かな印象を与える動作や手軽な動作が適切と評定され たのかもしれない。お辞儀の角度の浅さや静止時間の 短さはお辞儀にかかる全体の時間の短さとも関連があ り, 角度や静止時間のほか, お辞儀の速度など動作全 体の時間に関連した変数を操作した検討も必要かもし れない。

感謝場面では深いお辞儀が適切であるが，静止時間 はある程度長くなると角度によらず不適切と評定され る結果となった。謝罪場面では，深いお辞儀であった り，2 秒程度の静止時間であると，適切な動作である と評定された。また, 感謝場面の適切さは滑らかさと, 謝罪場面の適切さは丁寧さと, 正の相関関係にあった。 これらの結果は, 文脈によって適切なお辞儀の動作が 異なることを示すとともに，お辞儀の動きの中に感謝 や謝罪などの意図が表現されている可能性を示唆す る。本研究では CG のマネキンを刺激とした評定実験 を実施したが，人間は単純な罒形であってもその動き のパターンに応じてその動きの中にある意図を感じ取 ることがあることが知られている（Heider \& Simmel, 1944）。たとえば，円や三角といった単純な図形を用 いても, その動きのパターンに応じて, 追いかけてい る，などの意図を感じ取ることがある。頭を下げたり 下げた頭を静止させたりする動きはある意図を伝えて おり, 角度や静止時間の違いが伝達したい意図の種類 と関連している可能性が考えられる。

お辞儀における頭を下げる動作は，もともとは無抵 抗の表現で敵意がないこと, 服従を伝える動作であっ たという3。推測であるが，お辞儀の中に現れる無抵 抗な姿勢と感謝や謝罪などの意図の伝達が関連してい る可能性も考えられるかもしれない。ただし本研究で は感謝場面, 謝罪場面ともに静止時間が非常に長くな

\footnotetext{
3 相手への服従や敬意とお辞儀とを関連づけている文献とし て，たとえばMoris（1967）によれば，人間は他の霊長類と共通 してうずくまったり悲鳴をあげたりする服従の振る舞いを見せ るが, この弱い形のひとつとしてお辞儀をあげている。また Eibl-Eibesfeldt（1973）もお辞儀と服従的な姿勢とを関連づけて いる。荘厳（1986）は日本の拈辞儀の起源を僧侶の“扯”の姿 勢に見ている。仏の存在を崇めたてまつるために自分の姿勢を 極端に低くして地面にはいつくばるが，この姿勢が地位の高い 人物に対する拝礼の姿勢となり，地位にそれほど差がない関係 における儀礼の簡素化として低頭姿勢が用いられるようになり, お辞儀として広まったと考えられる, と記載している。また樋 口 (2011) は, お辞儀は無抵抗の表現で敬意をあらわすようになっ たのはむしろその後であること, 柴崎 (2008) は, お辞儀は急 所である頭部を相手に差し出し相手への敬意の深さを伝えよう とする仕草であること，を記載している。
} 
るとその適切さも低くなることが示された。このこと は単に服従的な姿勢を取ればよいのではなく，同級生 に対しての感謝, 謝罪の㧍辞儀としては服従的な姿勢 が強すぎるとその適切さが低くなる可能性も考えられ る。

本研究の課題と展望を挙げると, 本研究で得られた 知見が現実空間で行われるお辞儀の印象や適切さの評 価に対しても適用可能であるのか調べる必要があるだ ろう。たとえば括辞儀を行う人物と受け手との距離や 身長の違いなど，現実空間で行われるお辞儀の印象や 適切さの評価には様々な要因が影響を及ぼすと想定さ れる。また，本研究では三つの文脈を想定したが，実 際には㧍辞儀はより具体的な場面で行われ，その場面 も様々であろう。統制の難しさは問題となるが, 本研 究の結果が実際の場面で行われるお辞儀をどの程度説 明することができるのかについては検証が必要であろ う。

また，礼儀においては時，場所，場合に応じて適切 に振る舞えることが重要であり（古閑，2012），たと えば㧍辞儀を行う相手と適切なお辞儀の動作との関係 性を検討する必要があるだろう。本研究は大学生, 大 学院生を対象に, 同級生同士の文脈を想定して実験を 実施したが, 会社の上司や学生にとっての教師など, 目上の人間に対しても括辞儀は頻繁に行われると想定 される。お辞儀を行う人物とその受け手との関係性を 明らかにすることも意義深いと思われる。

このほか, 抒辞儀を扱った研究として近年, 白井・ 鈴木・阪田（2013）は相手に対して自発される抒辞儀 の時間, 深さ, タイミングの特徴をモーションキャプ チャを用いて定量的に調べており，また大杉・河原 （2013）はお辞儀が顔の魅力を向上させることを報告 している。しかし，括辞儀は日本人に非常に馿染みの ある動作であるが，実験を通じた心理学的な検討はま だ少ない。㧍辞儀を行う人物の立場や服装, 表情, 言 葉遣いなど本研究で操作しなかった要因の検討も必要 であろう。

本研究は $\mathrm{CG}$ を用いて運動学的な情報を操作した刺 激を用いた。形が整わないお辞儀は相手に不快な印象 を与える可能性があるが，運動学的な情報ばかりを身 に付けても礼を伝える気持ちや抒辞儀を行う理由の理 解を疎かにしては意味がないことが指摘されている (古閑, 2012)。外側に表現される形だけでなく，お辞 儀を行う人物の心理的, 精神的な側面にも着目して検 討することも重要であろう。

\section{引用文献}

大坊 郁夫 (1998). しぐさのコミュニケーション人は親しみをどう伝えあうか一一ーサイエンス社 (Daibo, I.)
Eibl-Eibesfeldt, I. (1973). Der vorprogrammierte Mensch: Das Ererbte als bestimmender Faktor im menschlichen Verhalten. Wien: Verlag Fritz Molden.

(アイブルーアイベスフェルト, I. 霜山 徳爾・岩 渕 忠敬（訳）（1977）。プログラムされた人間 —攻撃と親愛の行動学——平凡社)

福岡 慎介・柴田 寛・行場 次朗（2008）。おじぎの動 作変化が主観的印象と文脈に抒ける適切さに与え る影響 東北心理学研究 (東北心理学会発表抄 録), 58, 92 .

(Fukuoka, S., Shibata, H., \& Gyoba, J.)

Heider, F., \& Simmel, M. (1944). An experimental study of apparent behavior. American Journal of Psychology, $57,243-259$.

辺見一男・諌山 日奈子 (2010)。立礼動作の好及判 定システムの試作 電子情報通信学会技術研究報 告, HIP2010-70, 47-52.

(Hemmi, K., \& Isayama, H. (2010). Proposal for preferences in the measurement system of the humanbowing-motion in the standing position. IEICE Technical Report, HIP2010-70, 47-52.)

樋口 清之 (2011)。 日本の風俗の謎 大和書房

(Higuchi, K.)

古閑 博美 (2012)。辞儀への一考察——礼の身体技法 —— 嘉悦大学研究論集, 55, 57-71.

(Koga, H. (2012). A study of bowing: Four types of bow. Kaetsu University Research Review, 55, 57-71.)

松村 緑 (1967). 新しい作法 光文書院

(Matsumura, M.)

Moris, D. (1967). The naked ape. London: Jonathan Cape. （モリス，D. 日高 敏隆（訳）（1999）。裸のサル —動物学的人間像——角川書店)

森下 はるみ・岩下宜子（1985）。身ぶり・しぐさの 型——拈じぎ・あいさつ考——体育の科学, 35, 823-826.

(Morishita, H., \& Iwashita, N.)

小笠原 清信 (1975)。 日本の礼法 講談社

(Ogasawara, K.)

小笠原 清忠 (2007)。小笠原流礼法入門一一美しい姿 勢と立ち居振る舞い——アシェット婦人画報社 (Ogasawara, K.)

小熊貞子 - 馬場 眞知子 - 広田 妙子 - 越前谷明子 (2004)，会話の終結部に見られる非言語行動 多 摩留学生センター教育研究論集, 4, 33-38.

(Oguma, T., Baba, M., Hirota, T., \& Echizenya, A. (2004). Non-verbal behaviors at conversation closing. Bulletin of International Student Centers, Tama, 4, 33 -38$.

大杉 尚之・河原 純一郎 (2013)。拈辞儀は顔の主観 的魅力を飛躍的に向上させる 日本心理学会第 77 回発表論文集, 615.

(Osugi, T., \& Kawahara, J. (2013). Japanese bowing increases facial attractiveness. Proceedings of the 77th Annual Convention of the Japanese Psychological Association, 615.)

柴崎 直人（2000）。いま生きる礼儀作法 新潮社 (Shibazaki, N.)

柴崎 直人 (2004)。青少年女子の礼儀作法教育の留意 
点——イメジ比較による考察——国立オリン ピック記念青少年総合センター研究紀要, 4, 1723.

(Shibazaki, N. (2004). The important matter on the etiquette education in youth woman: The consideration by comparison of an image. Journal of National Olympics Memorial Youth Center, 4, 17-23.)

柴崎直人 (2008). イラスト図解 小笠原流 日本の 礼儀作用・しきたり—““なぜ”がわかればすぐ 身につく!一 PHP 研究所

(Shibazaki, N.)

白井 芳奈・鈴木 紀子・阪田 真已子 (2013). お辞儀 の定量的分析一ーインタビュアーの振る舞いが挨 拶行動に与える影響——ヒューマンインター フェース学会研究報告集, 15, 145-150.
(Shirai, K., Suzuki, N., \& Sakata, M. (2013). Quantitative analysis of bowing behavior: How one's gestures affect the other's greeting behavior. Correspondences on Human Interface, 15, 145-150.) 荘悠 舜哉 (1986). ヒトの行動とコミュニケーション —心理生物学的アプローチ——福村出版 (Sogon, S.)

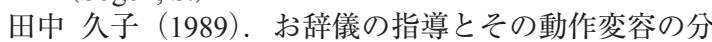
析 湘北紀要, 10, 39-50.

(Tanaka, H. (1989). An analysis of how teaching bowing brings about changes in the bowing movement. Journal of North Shore College, 10, 39-50.)

- 2014. 4.26 受稿, 2014. 7.12 受理 